\section{Scientific journal}

\section{PHYSICAL AND MATHEMATICAL EDUCATION}

Has been issued since 2013.

Науковий журнал

ФІЗИКО-МАТЕМАТИЧНА ОСВІТА

Видається з 2013.
ISSN 2413-158X (online)

ISSN 2413-1571 (print)

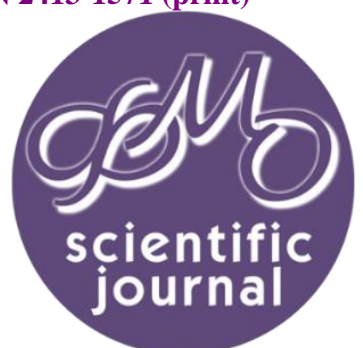

Гончаренко Я.В., Горбачук В.О. Модель комп'ютерно-орієнтованої методичної системи навчання статистики студентів економічних спеціальностей педагогічних університетів. Фізико-математична освіта. 2021. Випуск 1(27). С. 36-44.

Honcharenko Ya., Horbachuk V. Model of computer-oriented methodological system of teaching statistics for students of economic specialties of pedagogical universities. Physical and Mathematical Education. 2021. Issue 1(27). P. 36-44.

DOI 10.31110/2413-1571-2021-027-1-006

УДК 378

Я.В. Гончаренко

Начіональний педагогічний університет імені М.П. Драгоманова, Україна Goncharenko.ya.v@gmail.com ORCID: 0000-0003-2702-7847

B.О. Горбачук

Національний педагогічний університет імені М.П. Драгоманова, Україна v.o.horbachuk@npu.edu.ua ORCID: 0000-0003-2702-7847

\title{
МОДЕЛЬ КОМП'ЮТЕРНО-ОРІЄНТОВАНОЇ МЕТОДИЧНОЇ СИСТЕМИ НАВЧАННЯ СТАТИСТИКИ СТУДЕНТІВ ЕКОНОМІЧНИХ СПЕЦІАЛЬНОСТЕЙ ПЕДАГОГІЧНИХ УНІВЕРСИТЕТІВ
}

\section{АНОТАЦІЯ}

Формулювання проблеми. В силу існуючих протиріч між високими запитами суспільства та ринку праці до рівня математичної та IT-підготовки фахівців в галузі економіки та реальним рівнем сформованості відповідних компетентностей у студентів, невідповідності сучасного рівня розвитку комп'ютерно-орієнтованих технологій, що використовуються в освітній та професійній діяльності майбутніх економістів, та недостатнім обсягом або застарілим змістом їх використання в процесі навчання математичної статистики, актуальною $\epsilon$ проблема теоретичного обгрунтування, розробки та впровадження комп'ютерно-орієнтованої методичної системи навчання (КОМСН) математичної статистики майбутніх економістів.

Матеріали і методи. Під час дослідження були використані загальнотеоретичні педагогічні методи (аналіз і синтез, порівняння, узагальнення, класифікація), а також методи моделювання та аналізу педагогічних систем.

Результати. В статmі представлено модель КОМСН статистики студентів економічних спеціальностей педагогічних університетів. Охарактеризовано ії теоретико-методологічні основи, представлено результати розробки кожного з ії компонентів: сформульовано зовнішні та внутрішні цілі, визначено принципи відбору та структурування змісту навчання в умовах реалізації комп'ютерно-орієнтованого підходу, проаналізовано основні методи навчання та висвітлено особливості їх застосування, здійснено порівняльний аналіз традиційних та комп'ютерно-орієнтованих форм організації освітнього процесу. В роботі також проаналізовано та представлено результати досліджень щодо очікуваного ефекту від впровадження КОМСН статистики.

Висновки. Розробка та впровадження КОМСН математичної статистики студентів економічних спеціальностей педагогічних університетів сприятиме підвищенню рівнів срормованості їх математичних та ІТ-компетентностей, активізації пізнавальної діяльності, покращить рівень практичної та професійної підготовки.

КЛЮчОВІ СЛОВА: комп'ютерно-орієнтована методична система навчання, методика навчання статистики, иілі навчання, методи навчання, форми організації освітнього процесу, активізація пізнавальної діяльності.

\section{ВСТУП}

Постановка проблеми. Сучасне освітнє середовище характеризується високим рівнем інформатизації, що відбуваються в рамках загальних тенденцій розвитку технологій та освіти та сучасних вимог до формування у майбутніх фахівців системних інтегрованих знань та готовності їх використовувати в професійній діяльності.

На сучасному етапі вимоги до математичної освіти фахівців математичних та економічних спеціальностей зазнали суттєвих змін: дещо послабіла роль певних розділів класичної вищої математики і посилилась роль інших математичних дисциплін, зокрема: теорії ймовірностей та математичної статистики, чисельних методів, методів оптимізації та дослідження операцій, фінансової та актуарної математики тощо. Вивчення цих розділів математики $\epsilon$ необхідною умовою успішної професійної

(C) Я.В. Гончаренко, В.О. Горбачук, 2021. 
діяльності фахівця в майбутньому, оскільки формує здатність будувати та досліджувати математичні моделі, обґрунтовано та результативно застосувати ті чи інші математичні методи при розв'язуванні реальних професійних задач, розуміти та критично осмислювати зміст професійної, наукової та спеціальної літератури.

Математична статистика $€$ однією з провідних дисциплін в підготовці фахівців в галузі як математики, так $і$ економіки. Основними завданнями навчання статистики є: навчити студентів методам побудови статистичних та ймовірнісних математичних моделей, методам їх дослідження і розв'язування формалізованих задач, зокрема 3 використанням систем комп'ютерної математики; виробити у студентів уміння аналізувати різні способи розв'язання задач, порівнювати отримані результати, формулювати формальні та змістовні висновки; сформувати навички статистичного аналізу даних в тому числі з використанням різних типів сучасних програмних засобів.

Попри суттєві досягнення в напрямі розробки методів комп'ютерно-орієнтованого навчання математичних дисциплін, на сьогодні існують суперечності між:

- надшвидким оновленням комп'ютерно-орієнтованих технологій, що використовуються в освітній та професійній діяльності майбутніх фахівців, та недостатнім обсягом або застарілим змістом їх використання в процесі навчання статистики;

- професійними вимогами до рівня сформованості в майбутнього бакалавра економіки або математики (зі спеціалізацією «економіка») уміння створювати та досліджувати математичні та комп'ютерні моделі та реальним рівнем сформованості відповідних компетентностей у студентів.

Одним з реальних шляхів інформатизації освітнього процесу, підвищення якості професійної підготовки майбутніх фахівців, активізації навчально-пізнавальної і науково-дослідної діяльності студентів 3ВО, розкриття їхнього творчого потенціалу, збільшення ролі самостійної та індивідуальної роботи, за словами М. І. Жалдака, є створення і широке впровадження в повсякденну педагогічну практику нових комп'ютерно-орієнтованих методичних систем навчання (КОМСН) на принципах поступового і неантагоністичного, без руйнівних перебудов і реформ, вбудовування інформаційно-комунікаційних технологій у діючі дидактичні системи, гармонійного поєднання традиційних і комп'ютерно-орієнтованих технологій навчання, не заперечування і відкидання здобутків педагогічної науки минулого, а, навпаки, їх удосконалення і посилення, в тому числі і за рахунок використання досягнень у розвитку комп'ютерної техніки і засобів зв'язку" (Жалдак, 2003).

Аналіз актуальних досліджень. Проблеми створення і впровадження комп'ютерно-орієнтованих методичних систем навчання математики, інформатики, фізики у закладах середньої та вищої освіти досліджували М. Жалдак, Ю. Рамський, О. Гончарова, В. Клочко, Н. Морзе, С. Семеріков, В. Сергієнко, 3. Сейдаметова, Є. Смірнова-Трибульська, О. Співаковський, С. Раков, Ю. Триус, Є. Вінниченко, Ю. Горошко, О. Жильцов, Т. Зайцева, Т. Кобильник, Т. Крамаренко, В. Круглік, Ю. Лотюк, М. Львов, І. Лупан, А. Пеньков, Ю. Сінько, О. Смалько, Ю. Триус, С. Шокалюк та інші. Методичні системи, співвідношення та змістове наповнення їх компонент, а також шляхи оптимізації освітніх процесів вивчали Ю. Бабанський, В. Беспалько, Б. Блум, В. Боголюбов, О. Бугайов, В. Гузєєв, Л. Занков, О. Іваницький, Т. Ільїн, В. Крисько, І. Лернер, Т. Назарова, А. Новіков, В. Ортинський, А. Пишкало, Г. Селевко, Р. Манн, О. Кравченко, І. Ганжала, М. Снаткін, Г. Щукін, В. Якунін та інші.

Однак, вказані вище протиріччя, а також нагальна потреба системної інтеграції ІКТ в освітній процес призводить до необхідності створення відповідних комп'ютерно-орієнтованих методик навчання окремих дисциплін. Зазначені суперечності зумовлюють актуальність проблеми дослідження і визначають необхідність теоретичного обґрунтування, розробки та впровадження комп'ютерно-орієнтованої методики навчання статистики.

Зазначимо, що курс статистики на сьогодні вивчають в багатьох педагогічних університетах України студенти різних спеціальностей таких галузей знань як 07 Управління та адміністрування, а також 11 Математика та статистика.

Мета статті. Опис розробки та впровадження комп'ютерно-орієнтованої методики навчання статистики студентів економічних дисциплін педагогічних університетів.

\section{МЕТОДИ ДОСЛІДЖЕННЯ}

В дослідженні було застосовано теоретичні та емпіричні методи дослідження: аналіз наукової та науковометодичної літератури з проблем дослідження; аналіз освітніх програм, навчальних планів, підручників і навчальних посібників; узагальнення і систематизація, порівняльний та системний аналіз результатів наукових досліджень та наявного педагогічного досвіду); моделювання педагогічних процесів; спостереження (аналіз навчальних занять, результатів навчання, порівняння різних підходів до організації навчання математичної статистики в різних ЗВО України); діагностика (анкетування, тестування, бесіди, контрольні зрізи знань).

\section{РЕЗУЛЬТАТИ ДОСЛІДЖЕННЯ ТА ЇХ ОБГОВОРЕННЯ}

Комп'ютерно-орієнтованою методичною системою навчання (КОMСH) називають методичну систему навчання, використання якої забезпечує цілеспрямований процес здобування знань, набуття умінь і навичок, засвоєння способів пізнавальної діяльності суб'єктом навчання і розвиток його творчих здібностей на основі широкого використання інформаційно-комунікаційних технологій (Триус, 2005).

А. М. Пишкало (Пишкало, 1975), визначив методичну систему навчання як сукупність п'яти ієрархічно пов'язаних компонентів: цілей навчання, змісту, методів, засобів і організаційних форм навчання, що утворюють єдину цілісну функціональну структуру, орієнтовану на досягнення цілей навчання. Однак, на сьогодні традиційна модель методичної системи зазнає доповнень та розвитку в роботах багатьох вчених (Триус 2005, Морзе 2003, Жалдак, 2003). принципам:

Сучасна модель методичної системи навчання на думку Н.В. Морзе (Морзе, 2003), повинна відповідати наступним

1. Предметність моделі. Моделі навчання різних предметів можуть включати різні сукупності компонентів і ці компоненти - можуть знаходитися в специфічних для даного предмета відношеннях між собою. Отже, можна очікувати, що структурно методичні системи навчання різних предметів будуть відрізнятися, тобто матимуть певні особливості. 
2. Локальність моделі. Через істотні й все більш зростаючі розходження в цілях і умовах навчання в різних закладах освіти вже не можна говорити про методичну систему навчання предмету взагалі. В моделі необхідно враховувати не тільки розходження у навчанні різних предметів, але й особливості у вивченні предмета, що склалися в конкретному закладі освіти. Таким чином, в удосконаленій моделі методичної системи навчання необхідно враховувати локальні особливості навчання предмету, тобто змінювати від одного закладу освіти до іншого.

3. Динамічність моделі. Компоненти методичної системи, як правило, знаходяться у швидкому розвитку, регулярно перебудовуються зв'язки між цими компонентами. В методичній системі, як моделі навчання, необхідно передбачати розвиток практики навчання, включати компоненти, де передбачається розвиток їх змісту, перебудова їх структурних зв'язків.

В.П. Беспалько в роботі (Беспалько, 1989) відзначає, що “в сучасних умовах, коли комп'ютеризація освітнього процесу стає найближчою перспективою, педагогічне проектування - єдина умова його ефективної реалізації”.

Особливо актуальним є створення та оновлення методичних систем для дисциплін, які зазнають швидких змін; їх цілі, зміст, методи та технології швидко оновлюються під впливом викликів сучасного світу (Манн та ін., 2020). Це можна сказати і про курс статистики.

При розробці КОМСН математичної статистики необхідно враховувати наступні принципи: поступового i неантагоністичного вбудовування інформаційно-комунікаційних технологій у діючі дидактичні системи, гармонійного поєднання традиційних і комп'ютерно-орієнтованих технологій навчання, наступності здобутків педагогічної науки (класичних і нових перспективних), не заперечування і відкидання минулого досвіду а, навпаки, його удосконалення i посилення, в тому числі і за рахунок використання досягнень у розвитку комп'ютерної техніки і засобів зв'язку. (Триус, 2005).

\section{Теоретико-методологічні основи КОМСН}

Розроблена в даному дослідженні комп'ютерно-орієнтована методика навчання статистики грунтується на проведеному дослідженні теоретико-методологічних та психолого-педагогічних основ, що включало в себе: виділення провідних підходів та технологій навчання (діяльнісний, компетентнісний, системний, студентоцентрований); визначення основних принципів комп'ютерно-орієнтованого навчання; аналіз особливостей методології та методики навчання статистиків умовах інформатизації освіти; аналіз специфіки методичної системи навчання математичних дисциплін 3 використанням IKT; визначення місця та ролі комп'ютерно-орієнтованого супроводу в навчання статистики; дослідження та врахування психологічних особливостей студентів старших курсів бакалаврату в умовах зміни парадигми навчання та провідного типу діяльності з навчальної на навчально-професійну.

На основі здійсненого аналізу було сформульовано вимоги та відповідні рекомендації щодо всіх складових методичної системи навчання статистики.

\section{Рекомендації щодо формування цілей навчання}

При розробці комп'ютерно-орієнтованої методики навчання статистики на етапі формування цілей навчання необхідно врахувати наступні вимоги: при формуванні когнітивних цілей навчання необхідно враховувати необхідність формування у майбутніх фахівців здатності використовувати сучасний апарат математичної статистики в професійній діяльності для розв'язання прикладних задач економічного змісту з використанням сучасних інформаційних технологій та програмних засобів. Це приводить до необхідності формування у студентів знань та вмінь, що забезпечують оволодіння методами статистичного аналізу, сучасними програмними комплексами, що використовуються в професійній аналітичній діяльності, вміннями та навичками програмування окремих статистичних процедур та функцій. Зазначимо, що сформульовані вимоги стосуються як зовнішніх (предметно-орієнтованих) цілей навчальної дисципліни, так і внутрішніх (студентоорієнтованих) цілей навчання.

\section{Організація відбору та систематизації змісту навчання}

При відборі та систематизації змісту навчального матеріалу з курсу статистики в умовах реалізації комп'ютерноорієнтованої методики навчання, на нашу думку, необхідно системно впроваджувати комплекс багаторівневих практичних, професійно-орієнтованих завдань, в тому числі таких, що імітують професійну діяльність фахівця з статистики, розв'язання яких здійснюється з використанням різних типів програмних засобів.

При цьому при використанні програмних засобів в навчанні необхідно проводити їх диференціацію за ступенем автоматизації процесу розв'язання та «порогом входу» студента, тобто рівнем оволодіння знаннями та вміннями 3 інформатики та програмування, що дозволяють використовувати певний програмний засіб до розв'язування задач. 3 цієї точки зору в роботі використовується наступний підхід до типізації програмних засобів, які пропонується використовувати в процесі комп'ютерно-орієнтованого навчання статистики (рис. 1).

Проектуючи зміст теоретичного навчання та систему навчальних завдань з статистики, ми спирались на уточнені цілі навчання, а також на наступні принципи: послідовності та наступності, взаємозв'язку та взаємозалежності, чіткої ієрархії між складниками.

На основі зазначених принципів було сформульовано наступні вимоги до змісту теоретичного навчання та системи завдань з статистики:

- підпорядкованість всіх змістових одиниць основним цілям навчання, які сформульовані у вигляді очікуваних результатів (компетентностей);

- структурування і систематизації змісту теоретичного навчання з врахуванням сучасних вимог, принципу науковості, а також можливостей інтенсифікації вивчення теоретичного матеріалу за допомогою IKT;

- типізація навчальних завдань за особливостями і роллю застосування інформаційно-комунікаційних технологій у їх розв'язанні;

- дотримання послідовності подачі теоретичного матеріалу та завдань однієї групи принципам: від простого до складного, від стандартного до творчого, від конкретного до абстрактного;

- забезпечення взаємозв'язку між фундаментальною та професійною підготовкою. 


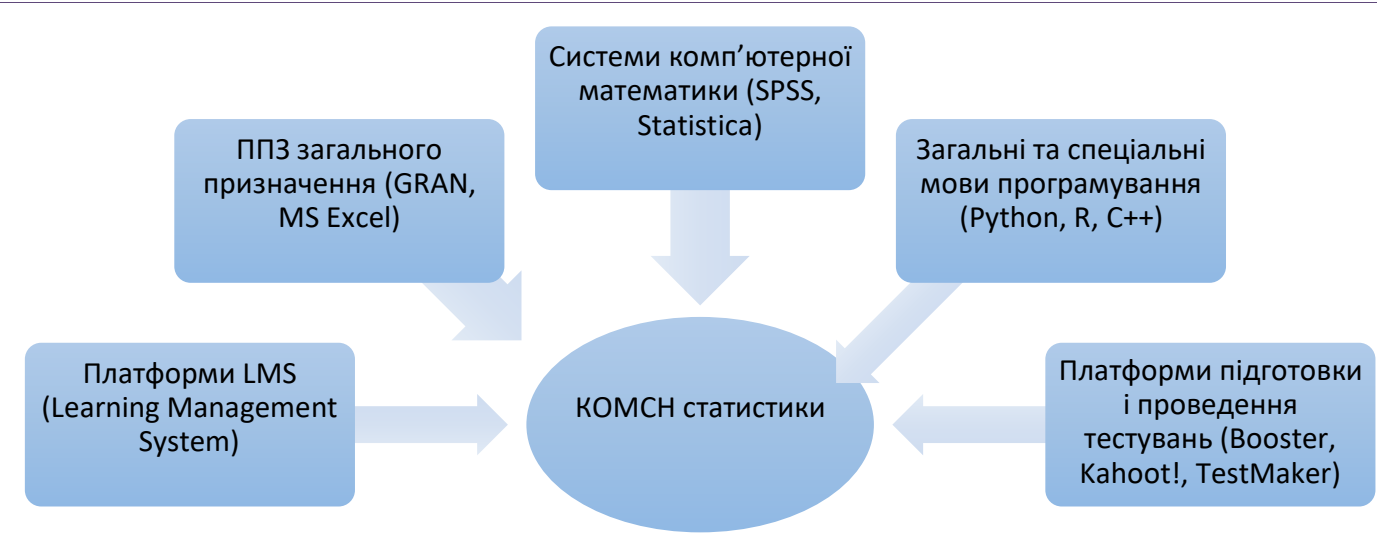

Рис. 1. Типи програмних засобів, які пропонується використовувати в процесі комп'ютерно-орієнтованого навчання статистики

Основним засобом реалізації принципу професійної спрямованості навчання математики $є$ система професійноорієнтованих завдань. Під професійно-орієнтованими завданнями часто розуміють деяку абстрактну модель реальної проблемної ситуації практичного характеру в професійній сфері діяльності, що сформульовано у вербальній, знаковій або образно-графічній формі, та що може бути розв'язана математичними засобами (Співаковський, 2003).

Отже, при створенні та реалізації комп'ютерно-орієнтованої методики навчання статистики необхідно використовувати систему послідовних взаємопов'язаних математико-статистичних, практичних та професійноорієнтованих задач, розв'язування яких передбачає використання різні типи програмних засобів, що створює умови для формування у студентів фундаменту для подальшого професійного навчання та майбутньої професійної діяльності.

Комп'ютерно-орієнтовані методи та засоби навчання, їх зв'язок з формами організації освітнього процесу

Методи навчання - це способи здійснення спільної діяльності педагога та студента. їх необхідно добирати так, щоб спонукати студентів до активної розумової діяльності, прагнення свідомо засвоїти зміст предмета, який вони вивчають (Морзе, 2003). Метод навчання є дуже складним, багатовимірним педагогічним явищем, в якому відображені об'єктивні закономірності, принципи, цілі, зміст, засоби і форми навчання. Найпоширенішими у професійній підготовці майбутніх фахівців у ЗВО є методи: словесні (розповідь, бесіда, дискусія, лекція); наочні (демонстрація); практичні (навчальнопрактичні роботи, робота з підручником, практикумом); індуктивні та дедуктивні; дослідницькі; проблемного викладу; репродуктивний метод вирішення завдань; активного навчання; контролю і самоконтролю та багато інших. Відомо, що загальних дидактичних методів навчання $€$ досить багато і їх класифікують за різними класифікаційними принципами. Найчастіше виділяють такі основні групи:

1) групи методів за типом та суттю взаємної навчальної роботи викладача і студентів: репродуктивний, пояснювально-ілюстративний, проблемного подання навчального матеріалу, евристичний, науково-пошуковий;

2) групи методів за основними складовими навчальної роботи викладача: а) проведення навчальної діяльності (словесні, наочні, репродуктивні й проблемні, індуктивні та дедуктивні, робота студентів самостійна та під керівництвом викладача); б) стимулювання і мотивації навчання (методи формування інтересу - пізнавальні ігри, аналіз життєвих ситуацій, створення ситуацій успіху; методи формування обов'язковості й відповідальності в навчанні - висвітлення суспільної й особистісної значимості навчання, встановлення навчальних результатів і педагогічних вимог); в) контролю і самоконтролю (контроль усний і письмовий, практичні, лабораторні і творчі роботи, контроль індивідуальний і загальний, поточний, рубіжний і підсумковий).

В останні роки під впливом розвитку комп'ютерних технологій та інформатизації освітнього процесу все ширше методи активізації навчально-пізнавальних дій студентів. У межах нових педагогічних технологій визначають такі найбільш ефективні методи активного навчання, як навчання у співробітництві, метод проектів, різнорівневе навчання, «портфель учня (студента)» (Полат, 1999).

На нашу думку, завдання вибору і застосування комп'ютерно-орієнтованих методів навчання у навчанні статистики має здійснюватись за наступним принципом: в конкретних умовах доцільно обирати ті методи, використання яких забезпечує високу ефективність навчання студентів за прийнятими критеріями.

Розглянемо основні групи методів (за класифікацією Ю.Бабанського) навчання та зупинимось на специфіці їх застосування в умовах реалізації КОМНС в навчанні статистики (табл. 1).

Слід зазначити, що якість підготовки майбутніх бакалаврів економіки та бакалаврів математики (з додатковою спеціалізацією «економіка» (вчителів математики та економіки) залежить не лише від глибини засвоєння теоретичних знань і набутих спеціальних умінь і практичних навичок, а й від сформованості здатності до творчого вирішення поставлених завдань, готовності вести дослідницьку діяльність. Вирішенню цієї проблеми сприяє впровадженні в освітній процес проблемно-дослідницьких методів навчання, серед яких особливо ефективним в навчанні статистики $\epsilon$ метод проектів (Стрельніков, 2004).

Застосування методу проектів стимулює студентів до вирішення певної проблеми, що потребує, з одного боку, відповідного рівня теоретичних знань, сформованості вмінь та навичок, в тому числі вмінь вести пошукову дослідницьку роботу, а з іншого - передбачає необхідність інтегрування знань та вмінь з різних галузей та вміння їх використати при вирішенні професійно-орієнтованих завдань (Gilford, 1994). 
Методи навчання в умовах реалізації КоМСН навчання статистики

\begin{tabular}{|c|c|c|}
\hline $\begin{array}{l}\text { Назва групи } \\
\text { методів }\end{array}$ & $\begin{array}{c}\text { Найбільш поширені методи, що } \\
\text { реалізуються в навчанні статистики }\end{array}$ & Комп'ютерний супровід методів в навчанні статистики \\
\hline \multicolumn{3}{|c|}{ Методи організації та здійснення навчально-пізнавальної діяльності } \\
\hline \multicolumn{3}{|c|}{ За джерелом передачі навчальної інфрормації } \\
\hline Словесні методи & розповідь-пояснення, бесіда, лекція & \multirow{2}{*}{$\begin{array}{c}\text { Створення багатофункціональних демонстраційних } \\
\text { мультимедійних систем (комп'ютер, електронна дошка, } \\
\text { мультимедійний проектор та ін.) для супроводу викладу } \\
\text { навчального матеріалу та демонстрації графічних, } \\
\text { текстових або звукових повідомлень }\end{array}$} \\
\hline Наочні методи & ілюстрація, демонстрація & \\
\hline $\begin{array}{l}\text { Практичні } \\
\text { методи }\end{array}$ & досліди, вправи, навчальна практика & $\begin{array}{c}\text { Виконання практичних професійно орієнтованих завдань } \\
\text { з використанням сучасних програмних засобів; } \\
\text { використання базових знань та вмінь з програмування } \\
\text { для реалізації алгоритмів розв'язання задач; проведення } \\
\text { обчислювальних експериментів }\end{array}$ \\
\hline \multicolumn{3}{|c|}{ За логікою передачі та сприймання навчальної інформації } \\
\hline Індуктивні & $\begin{array}{c}\text { Організація пізнавального процесу } \\
\text { від часткового до загального }\end{array}$ & \multirow{2}{*}{$\begin{array}{c}\text { Формулювання алгоритмів для розв'язання певних класів } \\
\text { завдань та їх подальша програмна реалізація сприяють } \\
\text { формуванню у студентів як індуктивного, так і } \\
\text { дедуктивного мислення та методу пізнання }\end{array}$} \\
\hline Дедуктивні & $\begin{array}{c}\text { Формування нових знань на основі } \\
\text { переходу від загального до } \\
\text { часткового }\end{array}$ & \\
\hline \multicolumn{3}{|c|}{ За ступенем самостійного мислення студентів у процесі оволодіння знаннями, формуванням умінь і навичок } \\
\hline Репродуктивні & Діяльність за зразком & $\begin{array}{c}\text { Використання електронних навчальних матеріалів, } \\
\text { готових запрограмованих форм для розв'язання } \\
\text { основних типів задач, вбудованих процедур та функцій та } \\
\text { відповідного електронного довідкового матеріалу }\end{array}$ \\
\hline $\begin{array}{l}\text { Проблемно- } \\
\text { пошукові }\end{array}$ & $\begin{array}{c}\text { Проблемний виклад, спільне } \\
\text { навчання, еврістичний виклад, метод } \\
\text { програмованих завдань }\end{array}$ & $\begin{array}{c}\text { Використання інтегрованих завдань (статистика та } \\
\text { інформатика і програмування), кейсів, системи } \\
\text { послідовних програмованих задач, диференційованих за } \\
\text { типом ПЗ та рівнем їх використання в процесі } \\
\text { розв'язання } \\
\end{array}$ \\
\hline Творчі & Дослідження, творче навчання & $\begin{array}{c}\text { Виконання практично орієнтованих проектів, які } \\
\text { передбачають самостійне виконання всіх етапів } \\
\text { статистичного дослідження з використанням IT (збір } \\
\text { даних, вибір моделей та методів аналізу, реалізація } \\
\text { математичних методів, отримання, аналіз та } \\
\text { інтерпретація результатів) }\end{array}$ \\
\hline \multicolumn{3}{|c|}{ За ступенем керівництва навчальною роботою } \\
\hline $\begin{array}{l}\text { Навчальна } \\
\text { робота під } \\
\text { керівництвом } \\
\text { викладача } \\
\end{array}$ & $\begin{array}{c}\text { Опрацювання теоретичного } \\
\text { матеріалу на занятті, письмові } \\
\text { самостійні роботи, індивідуальні } \\
\text { завдання } \\
\end{array}$ & $\begin{array}{c}\text { Електронні навчальні матеріали, автоматизовані системи } \\
\text { контролю (тестування) знань, електронні засоби зв'язку } \\
\text { та взаємодії викладача та студентів }\end{array}$ \\
\hline $\begin{array}{c}\text { Самостійна } \\
\text { робота учнів } \\
\text { поза контролем } \\
\text { викладача } \\
\end{array}$ & $\begin{array}{c}\text { Домашні завдання, розрахункові } \\
\text { роботи, самостійне вивчення } \\
\text { теоретичного матеріалу }\end{array}$ & $\begin{array}{c}\text { Використання LMS платформ для електронного навчання, } \\
\text { засобів дистанційного зв'язку та онлайн навчання } \\
\text { дозволяє покращити інформаційний супровід та } \\
\text { організувати зворотній зв'язок зі студентом }\end{array}$ \\
\hline \multicolumn{3}{|c|}{ Методи стимулювання та мотивації навчально-пізнавальної діяльності } \\
\hline $\begin{array}{c}\text { Методи } \\
\text { стимулювання } \\
\text { інтересу до } \\
\text { навчання } \\
\end{array}$ & $\begin{array}{c}\text { Дидактичні ігри, навчальні дискусії, } \\
\text { аналіз життєвих ситуацій }\end{array}$ & $\begin{array}{c}\text { Використання засобів онлайн та дистанційного навчання } \\
\text { для організації інтерактивної діяльності студентів; } \\
\text { використання практично орієнтованих завдань з } \\
\text { використанням професійних програмних засобів }\end{array}$ \\
\hline $\begin{array}{c}\text { Методи } \\
\text { стимулювання } \\
\text { обов'язку й } \\
\text { відповідальності }\end{array}$ & $\begin{array}{c}\text { Роз'яснення мети навчального } \\
\text { предмета, вимоги до вивчення } \\
\text { предмета, заохочення та покарання }\end{array}$ & $\begin{array}{c}\text { Використання систем управління навчальними курсами } \\
\text { (віртуальних навчальних середовищ типу Moodle) }\end{array}$ \\
\hline \multicolumn{3}{|c|}{ Методи контролю, самоконтролю, взаємоконтролю, корекції, самокорекції та взаємокорекції } \\
\hline Усні & $\begin{array}{l}\text { бесіда, опитування (індивідуальне та } \\
\text { групове), розповідь, роз'яснення }\end{array}$ & \multirow{4}{*}{$\begin{array}{l}\text { Використання онлайн платформ, електронних систем } \\
\text { тестування, розроблених комплексів тестових завдань, } \\
\text { комплексів завдань для лабораторно-практичних занять }\end{array}$} \\
\hline Письмові & контрольна робота, РГР, реферат & \\
\hline Практичні & Проведення дослідів & \\
\hline Тестові & $\begin{array}{c}\text { Виконання стандартизованих } \\
\text { завдань }\end{array}$ & \\
\hline
\end{tabular}




\begin{tabular}{|c|c|c|}
\hline $\begin{array}{c}\text { Назва групи } \\
\text { методів }\end{array}$ & $\begin{array}{c}\text { Найбільш поширені методи, що } \\
\text { реалізуються в навчанні статистики }\end{array}$ & Комп'ютерний супровід методів в навчанні статистики \\
\hline \multicolumn{3}{|c|}{ Бінарні та інтегровані методи навчання } \\
\hline Бінарні & $\begin{array}{c}\text { Поєднання двох методів або методу } \\
\text { та форми }\end{array}$ & $\begin{array}{c}\text { Використання лабораторно-практичних занять } 3 \\
\text { статистики; система завдань, що формують знання та } \\
\text { вміння застосовувати певні типи програмних засобів до } \\
\text { виконання окремих етапів статистичного дослідження } \\
\text { або розв'язання задач }\end{array}$ \\
\hline Інтегровані & $\begin{array}{c}\text { Поєднання кількох методів в єдину } \\
\text { систему }\end{array}$ & $\begin{array}{c}\text { Виконання проектів та індивідуальних завдань, що } \\
\text { передбачають застосування математико-статистичних } \\
\text { методів до розв'язання практичних завдань } \\
\text { економічного змісту та їх реалізацію в певному } \\
\text { програмному середовищі. }\end{array}$ \\
\hline
\end{tabular}

Використання у процесі вивчення дисциплін творчих, дослідницьких, міжпредметних й інших проектів розвиває у студента пізнавальну самостійність, формує вміння прогнозувати результати і можливі наслідки різних варіантів вирішення проблем, з'ясовувати причинно-наслідкові зв'язки, перетворює його з пасивного споглядача навчального матеріалу на активного учасника професійно-спрямованої навчально-пізнавальної діяльності. Реалізація методу проектів змінює також позицію викладача, перетворюючи його з носія готових знань на організатора-консультанта щодо коригування та координування роботи студентів над проектом: обговорення виконання проекту, коригування спільних та індивідуальних зусиль, організація презентації одержаних результатів і можливих способів їх впровадження в практику, зовнішнє оцінювання проекту (Коваль, 2009).

Отже, методичними умовами застосування комп'ютерно-орієнтованих методів навчання статистики, на нашу думку, є:

- Вільний доступ кожного студента до комп'ютерно-орієнтованого забезпечення дисципліни;

- Створення багатофункціональних демонстраційних мультимедійних систем (комп'ютер, електронна дошка, мультимедійний проектор та ін.) для супроводу викладу навчального матеріалу;

- Розробка практичних професійно-орієнтованих завдань, які передбачають використання сучасних програмних засобів, базових знань та вмінь з інформатики та програмування для реалізації методів та алгоритмів розв'язання;

- Використання засобів онлайн та дистанційного навчання для організації інтерактивної діяльності студентів;

- Використання систем управління навчальними курсами (віртуальних навчальних середовищ типу Moodle), piзних типів прикладних програмних засобів, електронних систем тестування, LMS платформ для електронного навчання, засобів дистанційного зв'язку та онлайн навчання тощо;

- Реалізація практичних методів навчання у формі лабораторно-практичних занять з статистики, з використанням розробленої для них системи завдань, що формують знання та вміння застосовувати певні типи програмних засобів до виконання окремих етапів статистичного дослідження або розв'язання задач;

- Використання інтегрованих завдань (статистика та інформатика і програмування), кейсів, системи послідовних програмованих задач, диференційованих за типом ПЗ та рівнем їх використання в процесі розв'язання;

- Виконання проектів та індивідуальних завдань, що передбачають застосування математико-статистичних методів до розв'язання практичних завдань економічного змісту та їх реалізацію в певному програмному середовищі.

Зрозуміло, що вибір методів навчання взаємообумовлений з вибором засобів навчання та формами організації освітнього процесу. Зупинимось детальніше на основних видах занять з статистики та охарактеризуємо їх специфіку в умовах реалізації КОМСН (табл. 2).

Таблиця 2

Порівняння традиційних та комп'ютерно-орієнтованих форм навчання

\begin{tabular}{|c|c|}
\hline Традиційна методична система & Комп'ютерно-орієнтована методична система \\
\hline Лекція & Комп'ютерно-орієнтована лекція \\
\hline Основна дидактична мета: формування & Основна дидактична мета: формування нових знань та вмін \\
\hline нових знань (засвоєння теоретичного & Провідні методи ю \\
\hline матеріалу). & Провідний тип діяльності студентів: частково-пошуковий. \\
\hline $\begin{array}{l}\text { Провідні методи навчання: словесні та } \\
\text { наочні. }\end{array}$ & $\begin{array}{l}\text { Переваги: підвищується рівень наочності, відбувається економія } \\
\text { навчального часу на певних етапах заняття, що дозволяє збагатити зміст }\end{array}$ \\
\hline $\begin{array}{l}\text { Провідний тип діяльності студентів: } \\
\text { репродуктивний. }\end{array}$ & $\begin{array}{l}\text { навчального матеріалу та здійснити інтеграцію математичних та } \\
\text { комп'ютерно-орієнтованих знань, вмінь та навичок. }\end{array}$ \\
\hline Практичне заняття & Лабораторно-практичне заняття \\
\hline $\begin{array}{l}\text { Основна дидактична мета: формування } \\
\text { вмінь та навичок застосовувати } \\
\text { теоретичні відомості до розв'язання } \\
\text { задач. } \\
\text { Провідні методи навчання: словесні, } \\
\text { наочні, практичні. } \\
\text { Провідний тип діяльності студентів: } \\
\text { репродуктивнийта частково-пошуковий. }\end{array}$ & $\begin{array}{l}\text { Основна дидактична мета: формування вмінь та навичок розв'язувати } \\
\text { певний клас задач з використанням IT технологій та програмних засобів. } \\
\text { Провідні методи навчання: практичні. } \\
\text { Провідний тип діяльності студентів: частково-пошуковий, пошуковий, } \\
\text { дослідницький. } \\
\text { Переваги: підвищується рівень самостійності студентів; з'являється } \\
\text { можливість ширше впроваджувати в освітній процес професійно- } \\
\text { орієнтовані задачі прикладного характеру, одночасно відбувається } \\
\text { формування як математичних, так і ІТ компетентностей студентів. }\end{array}$ \\
\hline
\end{tabular}


Продовження табл. 2

\section{Традиційна методична система Контроль (контрольна робота, залік, іспит)}

Форма організації навчальної діяльності, спрямована на виявлення й оцінювання ступеня оволодіння студентами знаннями, уміннями та навичками, що контролює рівень засвоєння визначеного обсягу навчального матеріалу в межах теми, розділу, модуля або навчальної дисциплін.

\section{Комп'ютерно-орієнтована методична система}

\section{Комп'ютерно-орієнтована форма контролю}

Основною особливістю $€$ те, що студент використовує комп'ютер або для безпосереднього вирішення завдань за допомогою проблемноорієнтованої програми і/або для проходження комп'ютерноорієнтованого контролю, наприклад, комп'ютерного тестування.

Переваги: економія часу, можливість автоматизовано здійснити перевірку рівня сформованості основних знань, вмінь та навичок, автоматизувати окремі етапи розв'язання та перевірки задач.

На основі проведеного аналізу та визначення основних складових КОМСН статистики було розроблено модель ї̈ реалізації (рис. 2).

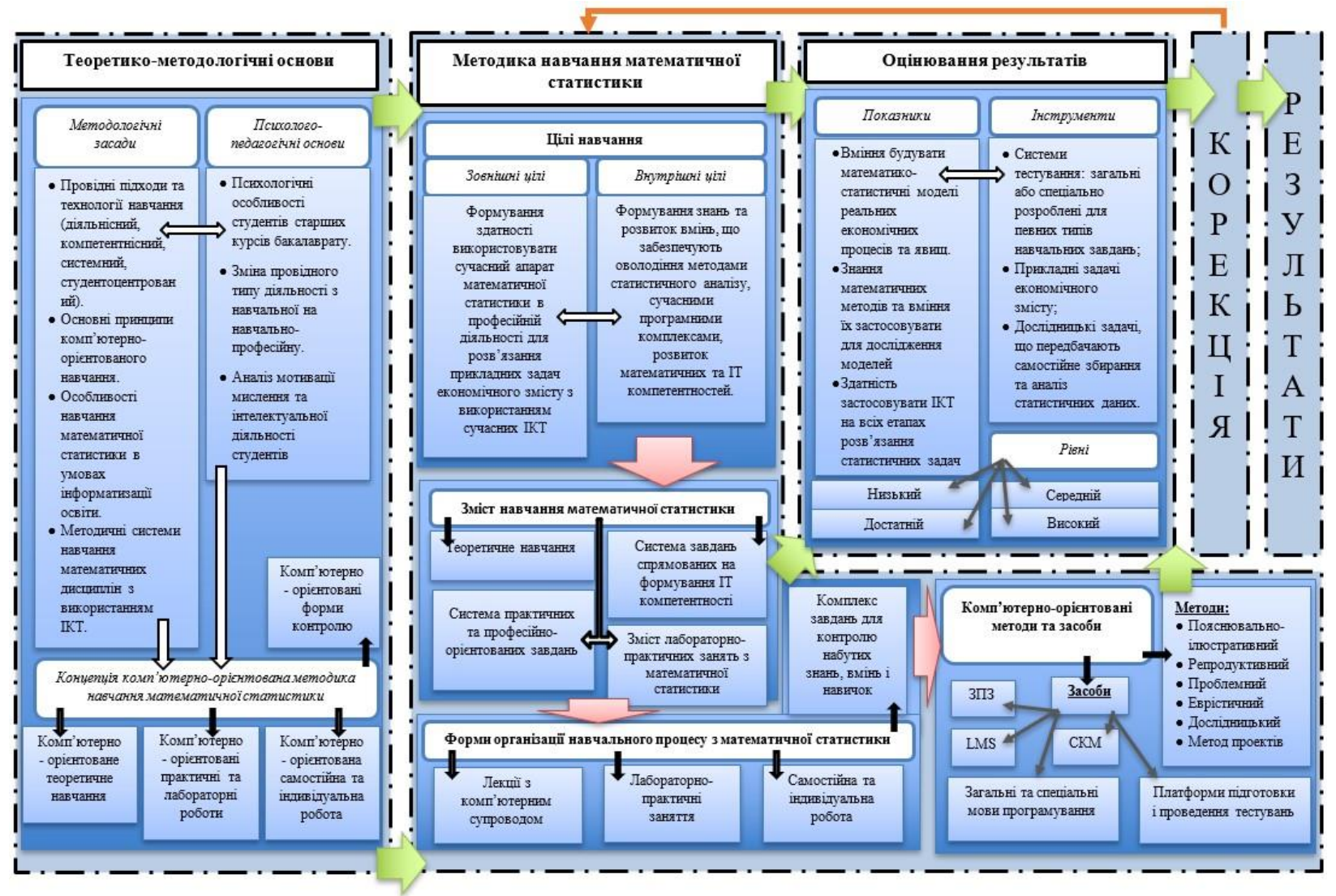

Рис. 2. Модель розробки та впровадження комп'ютерно-орієнтованої методики навчання статистики

При цьому очікуваним результатом від впровадження $\epsilon$ підвищення рівнів сформованості математичних та IT компетентностей студентів бакалаврату економічних та математичних (з додатковою спеціалізацією "економіка») спеціальностей, активізація їх пізнавальної діяльності, покращення рівня практичної та професійної підготовки.

Підводячи підсумок, можна констатувати, що розроблена модель комп'ютерно-орієнтованої методичної системи навчання статистики враховує цілі, зміст та організаційні умови здійснення підготовки здобувачів освіти освітнього рівня "бакалавр" галузей знань 07 Управління та адміністрування та 11 Математика та статистика. Враховуючи досвід впровадження даної моделі в НПУ імені М.П. Драгоманова, ми вважаємо, що вона дозволяє забезпечити підвищення якості формування математичних та IT-компетентностей майбутніх фахівців. Подальші дослідження, на нашу думку, можуть бути присвячені аналізу результатів впровадження та розробці показників ефективності розробленої методичної системи

\section{ВИСНОВКИ ТА ПЕРСПЕКТИВИ ПОДАЛЬШОГО ДОСЛІДЖЕННЯ}

На нашу думку, використання комп'ютерно-орієнтованих методик та технологій дає цілу низку методичних та методологічних переваг у порівнянні з традиційним навчанням. Це насамперед стосується активізації навчальнопізнавальної діяльності студентів, яка інтенсифікується за рахунок цілого рядку факторів:

- формування позитивної мотивації, інтересу до навчання,

- розвиток мислення та інтелектуальних здібностей,

• підготовка до практичної та професійної діяльності в умовах інформаційного суспільства, 
- підвищення рівня самостійності, індивідуалізація та диференціація,

- переважання активних методів навчання,

- підвищення рівня наочності, спрощення та збільшення швидкості доступу до навчальних та наукових інформаційних джерел,

- розширення кола задач і вправ,

- проведення лабораторних робіт у процесі навчання математичних дисциплін,

- опанування сучасними методами наукового пізнання, пов'язаними із застосуванням IKT

\section{Список використаних джерел}

1. Жалдак М. І. Педагогічний потенціал комп'ютерно-орієнтованих систем навчання математики. Комп'ютерноорієнтовані системи навчання: 36. наук. праць / Редкол. К.: НПУ імені М. П. Драгоманова, 2003. Випуск 7. С. 3-16.

2. Триус, Ю.В. Комп'ютерно-орієнтовані методичні системи навчання математики: [монографія]. Черкаси: БрамаУкраїна, 2005. $400 \mathrm{c}$.

3. Пышкало А. М. Методическая система обучения геометрии в начальной школе: Авторский доклад по монографии «Методика обучения геометрии в начальных классах», предст. на соиск. уч. степ. докт. пед. наук. М., 1975. 60 с.

4. Морзе Н. В. Основи методичної підготовки вчителя інформатики. Монографія. К.: Курс, 2003. 372 с.

5. Беспалько В. П. Слагаемые педагогической технологии. М.: Педагогика, 1989. С. 13

6. Триус Ю.В. Комп'ютерно-орієнтовані методичні системи навчання математичних дисциплін у вищих навчальних закладах: Автореф. дис. д-ра пед. наук: 13.00.02. К.: Нац. пед. ун-т ім. М.П.Драгоманова, 2005. 48 с.

7. Співаковський О.В. Теорія і практика використання інформаційних технологій у процесі підготовки студентів математичних спеціальностей. Херсон: Айлант, 2003. 229 с.

8. Полат Е. С. Новые информационные технологии в системе образования: учеб. пособие. М.: Академия, 1999. С. 15-16

9. Стрельніков В. Ю. Проектна освіта і технологія проектного навчання у вищій школі. Неперевна професійна освіта: теорія і практика. 2004. Вип. 1. С. 63-69.

10. Gifford S. Evaluating the Surrey New Teacher Competency Profile. British journal of in-service education. 1994. № 3.

11. Коваль Т. І. Підготовка викладачів вищої школи: інформаційні технології у педагогічній діяльності: навч.-метод. посібник. К.: КНЛУ, 2009. 380 с.

12. Манн, Р. В., Кравченко, О. В., \& Ганжала, І. В. (2020). Використання інформаційно-комунікаційних технологій як елемент інноваційного навчання фахівців економічного спрямування. Інформаційні технології $i$ засоби навчання, 78(4), 145-162. https://doi.org/10.33407/itlt.v78i4.2810.

\section{References}

1. Zhaldak M.I. (2003) Pedahohichnyi potentsial kompiuterno-oriientovanykh system navchannia matematyky. Kompiuternooriientovani systemy navchannia [Pedagogical potential of computer-oriented systems of teaching mathematics. Computerbased learning systems]: Coll. Science. works / Redcol. MP Drahomanov National Pedagogical University, 7. 3-16. [in Ukrainian].

2. Trius, Yu.W. (2005) Kompiuterno-oriientovani metodychni systemy navchannia matematyky: [monohrafiia].[Computeroriented methodical systems of teaching mathematics: [monograph]. BramaUkraine, 400 [in Ukrainian].

3. Pyshkalo A.M. (1975) Metodicheskaja sistema obuchenija geometrii v nachal'noj shkole: Avtorskij doklad po monografii «Metodika obuchenija geometrii v nachal'nyh klassah» [Methodical system of teaching geometry in primary school: Author's report on the monograph "Methods of teaching geometry in primary school"], 60 [in Russian].

4. Morse N.V. (2003) Osnovy metodychnoi pidhotovky vchytelia informatyky. Monohrafiia [Fundamentals of methodical training of computer science teachers. Monograph]. Kurs, 372 [in Ukrainian].

5. Bespalko V.P. (1989) Slagaemye pedagogicheskoj tehnologii [Terms of pedagogical technology], Pedagogika, 13 [in Russian].

6. Trius Yu.V. (2005) Kompiuterno-oriientovani metodychni systemy navchannia matematychnykh dystsyplin u vyshchykh navchalnykh zakladakh: Avtoref. dys. d-ra ped. nauk: 13.00.02. [ Computer-oriented methodical systems of teaching mathematical disciplines in higher educational institutions: Abstract. dis. Dr. Ped. Science: 13.00.02], Nat. ped. Univ. M.P. Dragomanova, 48 [in Ukrainian].

7. Spivakovsky O. V. (2003) Teoriia i praktyka vykorystannia informatsiinykh tekhnolohii u protsesi pidhotovky studentiv matematychnykh spetsialnostei [Theory and practice of using information technology in the process of training students of mathematical specialties]. Aylant, 229 [in Ukrainian].

8. Polat E.S. (1999) Novye informacionnye tehnologii v sisteme obrazovanija: ucheb. posobie [New information technologies in the education system: textbook. allowance]. Akademiya, 15-16 [in Russian].

9. Strelnikov V.Y. (2004) Proektna osvita i tekhnolohiia proektnoho navchannia u vyshchii shkoli [Project education and technology of project education in higher education], Continuing professional education: theory and practice, 63-69 [in Ukrainian].

10. Gifford S. Evaluating the Surrey New Teacher Competency Profile. British journal of in-service education. 1994. № 3. [in English]

11. Koval T.I. (2009) Pidhotovka vykladachiv vyshchoi shkoly: informatsiini tekhnolohii u pedahohichnii diialnosti: navch.-metod. Posibnyk [Preparation of high school teachers: information technology in teaching: teaching method. Manual], KNLU, 380 [in Ukrainian].

12. Mann, R. V., Kravchenko, O. V., \& Hanzhala, I. V. (2020). Vykorystannia informatsiino-komunikatsiinykh tekhnolohii yak element innovatsiinoho navchannia fakhivtsiv ekonomichnoho spriamuvannia [The use of information and communication technologies as an element of innovative training of specialists in the economic field]. Information Technologies and Learning Tools, 78(4), 145-162. https://doi.org/10.33407/itlt.v78i4.2810. [in Ukrainian] 
MODEL OF COMPUTER-ORIENTED METHODOLOGICAL SYSTEM OF TEACHING STATISTICS FOR STUDENTS OF ECONOMIC SPECIALTIES OF PEDAGOGICAL UNIVERSITIES

Yanina Honcharenko, Vasyl Horbachuk

National Pedagogical Dragomanov University, Ukraine

Abstract.

Formulation of the problem. Due to the existing contradictions between the highest demands of society and the labor market to the level of mathematical and IT training in economics and the student's real level of formation of relevant competencies, the inconsistency of the current level of computer-based technologies used in educational and professional activities of future economists, and insufficient or outdated content of their use in the process of teaching mathematical statistics. The problem of theoretical justification, development and implementation of computer-based methodological system of teaching (COMSN) of mathematical statistics of future economists is also relevant.

Materials and methods. General theoretical pedagogical methods (analysis and synthesis, comparison, generalization, classification), as well as methods of modeling and analysis of pedagogical systems were used during the research.

Results. The articles present the model of COMST statistics of students of economic specialties of pedagogical universities. Its theoretical and methodological bases are characterized, the results of development of all its components are presented: the external and internal purposes are formed, the principles of selection and structuring of the content of teaching in the conditions of realization of the computer-oriented approach are defined, the basic teaching methods are analyzed that the analysis of traditional and computeroriented forms of organization of educational process is made. The paper also analyzes and presents the results of research on the expected effect of the implementation of COMST statistics.

Conclusions. Development and implementation of COMST mathematical statistics for students of economic specialties of pedagogical universities to increase the level of formation of their mathematical and IT competencies, intensification of cognitive activity, improving the level of practical and professional training.

Keywords:. computer-oriented methodical system of teaching, methods of teaching statistics, learning objectives, teaching methods, forms of organization of the educational process, activation of cognitive activity. 